\title{
Deteksi Kerawanan Banjir Genangan Menggunakan Topographic Wetness Index
}

\section{Fitria Nucifera, Sutanto Trijuni Putro}

Masuk: 21102017 / Diterima: 30122017 / Dipublikasi: 31122017

(c) 2017 Fakultas Hukum dan IImu Sosial UNDIKSHA dan IGI

\begin{abstract}
Flood is the most frequent disaster occured in Indonesia. Flood events result in loss and damage to communities and the environment. Floods are triggered by several factors including hydrometeorological factors, topography, geology, soil and human activities. Topographic factor is one of the flood trigger control factors. Topographic calculation for flood inundation detection can be done by Topographic Wetness Index (TWI) method. The TWI method focuses on topographic conditions of the region, especially the upper slopes and lower slopes to assess the trend of water accumulation in a region. TWI calculations are based on the topography of an area represented by DEM (Digital Elevation Model) data in the form of DTM (Digital Terrain Model). The high value of TWI is associated with high flood vulnerability. Based on the calculation of TWI value, flood-prone areas in Kebumen District include Adimulyo Subdistrict, Mirit Subdistrict, Ambal Subdistrict, Rowokele Subdistrict, Sruweng Subdistrict and Buayan Subdistrict.
\end{abstract}

Key words: Flood, Topographic Wetness Index, Vulnerability

Abstrak Banjir merupakan kejadian bencana yang paling sering terjadi di Indonesia. Kejadian banjir mengakibatkan kerugian dan kerusakan bagi masyarakat dan lingkungan. Banjir dipicu oleh beberapa faktor antara lain faktor hidrometeorologi, topografi, geologi, tanah dan aktivitas manusia. Faktor topografi merupakan faktor kontrol pemicu banjir. Perhitungan topografi untuk deteksi kerawanan banjir genangan dapat dilakukan dengan metode Topographic Wetness Index (TWI). Metode TWI mentikberatkan pada kondisi topografi daerah khususnya lereng atas dan lereng bawah untuk menilai kecenderungan akumulasi air pada suatu daerah. Perhitungan TWI didasarkan pada topografi suatu daerah yang direpresentasikan dengan data DEM (Digital Elevation Model) dalam bentuk DTM (Digital Terrain Model). Besarnya nilai TWI berasosiasi dengan tingginya kerawanan banjir. Berdasarkan perhitungan nilai TWI, daerah rawan banjir di Kabupaten Kebumen meliputi Kecamatan Adimulyo, Kecamatan Mirit, Kecamatan Ambal, Kecamatan Sruweng, Kecamatan Rowokele dan Kecamatan Buayan.

Kata kunci : Banjir, Topographic Wetness Index, Kerawanan

\section{Pendahuluan}

Kejadian bencana mengakibatkan kerugian yang besar dalam berbagai

Fitria Nucifera

Prodi Geografi, Faktultas Sains dan Teknologi

Universitas AMIKOM Yogyakarta

fnucifera@amikom.ac.id

Sutanto Trijuni Putro

Prodi Teknik Kelautan, Fakultas Teknologi Sumberdaya

Alam, Institut Teknologi Yogyakarta

sutanto0612@gmail.com bidang. Sebanyak $70 \%$ kejadian bencana yang terjadi di dunia merupakan bencana hidrometeorologis (WMO, 2009). Posisi geografis Indonesia yang berada di zona ITCZ (Inter Tropical Convergence Zone) menjadikan Indonesia memiliki curah hujan yang melimpah sepanjang tahun (Aldrian et.al, 2005). Interaksi antara curah hujan yang melimpah dengan 
kondisi fisik lingkungan yang ada di Indonesia memicu banyaknya kejadian banjir yang terjadi di Indonesia.

Berdasarkan data yang tercatat BNPB sejak tahun 1815 hingga 2017 telah terjadi sebanyak 7.365 kejadian banjir di Indonesia (BNPB, 2017). Banjir merupakan kejadian bencana yang paling banyak terjadi di Indonesia. Propinsi Jawa Barat dan Jawa Tengah menduduki peringkat pertama dan kedua daerah dengan frekuensi kejadian banjir paling banyak.

Kejadian banjir dipengaruhi oleh faktor topografi, hidrometeorologi, geologi, tanah dan aktivitas manusia (Maidment, 1992). Faktor tersebut saling berkaitan satu sama lain. Topografi merupakan salah satu kontrol penting dalam distribusi spasial kondisi hidrologi (Sorensen et al., 2006). Perbedaan kondisi topografi akan mempengaruhi respon terhadap hujan yang jatuh di suatu daerah (Diakakis, 2011). Banjir merupakan kejadian hidrologi yang juga berhubungan dengan faktor topografi. Kejadian banjir berasosiasi dengan topografi tertentu. Sebagian besar kejadian banjir terjadi pada topografi datar, landai dan cekungan.

Topographic Wetness Index (TWI) merupakan metode kuantifikasi kontrol topografi terhadap proses hidrologi (Pourali et al., 2014). Sebaran spasial kondisi hidrologi dapat dipetakan menggunakan metode ini. TWI menilai secara kuantitatif efek topografi lokal terhadap limpasan air hujan (Qin et al., 2011). Nilai TWI mendeskripsikan kecenderungan akumulasi air pada sebuah lereng berdasarkan gaya gravitasi yang mengontrol aliran air (Pourali et al., 2014). TWI dapat diaplikasikan secara efektif untuk mengidentifikasi daerah rawan banjir dengan memetakan daerah yang mengalami genangan (Aksoy et al., 2016). Penilaian TWI dewasa ini dimplementasikan dengan Digital Elevation Model (DEM).

Pourali et.al (2014) menggunakan TWI intuk mengidentifikasi risiko banjir untuk perencanaan penggunaan lahan di Wreck Creek Australia. Pemetaan area dengan risiko banjir membantu dalam perencanaan wilayah yang aman dari bencana. Aksoy et.al (2016) menjadikan TWI sebagai salah satu parameter dalam membuat pemodelan kerawanan banjir. TWI digunakan sebagai dasar penentuan daerah yang rawan terjadi genangan berdasarkan nilai indexnya. Koriche (2010) melakukan pemodelan banjir untuk membangun sistem peringatan dini banjir. Salah satu parameter dalam pemodelan banjir adalah TWI. TWI dikombinasikan dengan SPI (Standard Precipitation Index) untuk memodelkan banjir. Haas (2010) menggunakan TWI dalam pemodelan kelembaban tanah. TWI menggambarkan nilai kebasahan lahan yang secara tidak langsung juga berkaitan dengan kelembaban tanah.

Secara konseptual, nilai TWI menggambarkan tingkat kebasahan lahan yang diasumsikan berasosiasi dengan kerawanan terhadap bencana banjir khususnya banjir genangan. Penilaian TWI yang dimplementasikan dengan menggunakan Digital Elevation Model (DEM) dalam bentuk Digital Terrain Model (DTM). Survei lapangan dilakukan untuk mengetahui validasi hasil pemetaan kerawanan banjir. 
Penelitian ini difokuskan untuk mengetahui sebaran spasial daerah rawan banjir berdasarkan nilai TWI serta untuk mengetahui akurasi penggunaan nilai TWI dalam penentuan kerawanan banjir. Pemetaan kerawanan banjir merupakan salah satu aplikasi geografi dalam bidang kebencanaan lingkungan terutama bencana tropic (Suarna, 2013). Studi kasus dilakukan untuk wilayah Kabupaten Kebumen. Kabupaten Kebumen merupakan salah satu wilayah di Propinsi Jawa Tengah yang mengalami banjir genangan secara periodik.

Kabupaten Kebumen memiliki variasi morfologi yang beragam, dari pegunungan hingga dataran. Hal ini diasumsikan dapat memberikan nilai TWI yang bervariasi. Hasil pemetaan TWI diharapkan dapat menjadi salah satu upaya mitigasi bencana di Kabupaten Kebumen.

\section{Metode}

Topographic Wetness Index (TWI) pertama kali dikembangkan oleh Beven dan Kirby (1979) sebagai bagian dari pemodelan runoff. TWI menilai efek topografi lokal terhadap runoff yang dihasilkan (Wilson and Gallant, 2000). Penilaian TWI dapat digunakan secara luas dalam pemodelan proses hidrologi, proses biologi, pola vegetasi dan kehutanan (Sorensen et al., 2006).

Berdasarkan Beven and Kirby (1979), formula utama yang digunakan dalam perhitungan TWI sebagai berikut:

$$
\mathrm{W}=\ln \frac{\alpha}{\tan \beta}
$$

Nilai $\mathrm{W}$ adalah wetness index dimana $\alpha$ merupakan akumulasi lereng bagian atas yang mengalirkan air pada suatu titik di setiap unit kontur, sedangkan $\beta$ merupakan sudut lereng pada titik tersebut.

Index tersebut menggambarkan kecenderungan air untuk terakumulasi pada satu titik berdasarkan gaya gravitasi dimana air selalu mengalir ke tempat yang lebih rendah (Quin et al., 1991). Dalam hal ini air mengalir menuju lereng bawah. Dengan demikian nilai index akan semakin besar pada lereng yang sangat datar dan sebaliknya nilai index semakin kecil pada lereng yang curam (Haas, 2010). Apabila suatu daerah terakumulasi aliran air maka tanah akan menjadi jenuh air. Air akan menggenang karena pori-pori tanah sudah tidak mampu menampung air. Daerah dengan nilai TWI yang tinggi cenderung lebih rawan untuk mengalami banjir genangan.

Data utama yang digunakan dalam penelitian ini adalah data DEM dari citra ASTER dengan resolusi 10 meter. Data DEM diperoleh dari USGS (United States Geological Survey). Data DEM ini selanjutnya dikonversi menjadi DTM sebelum dianalisis. DTM menggambarkan elevasi permukaan bumi yang sebenarnya tanpa adanya bias ketinggian pada pengunaan lahan. DTM digunakan sebagai data dasar dalam analisis TWI yang diintegrasikan dengan SIG (Sistem Informasi Geografis). Pengolahan data DEM menjadi TWI dilakukan dengan menggunakan software SAGA GIS.

Resolusi spasial data DEM merupakan poin penting dalam analisis lingkungan 
(Price, 1990). Pemilihan data DEM dengan resolusi yang tepat disesuaikan dengan tujuan penelitian. Distribusi spasial TWI tergantung pada resolusi spasial data DEM. Beberapa penelitian menyatakan bahwa semakin rendah resolusi spasial grid sel menghasilkan rata-rata nilai TWI yang lebih tinggi and interval yang lebih panjang (Haas, 2010; Jenson, 1991; Seibert et al., 2007). Analisis kerawanan banjir pada penelitian ini dibatasi untuk skala 1:100.000.

Penentuan daerah rawan banjir dilakukan berdasarkan hasil perhitungan TWI setelah dilakukan normalisasi. Normalisasi data TWI dilakukan untuk mempermudah analisis data. Normalisasi nilai TWI dilakukan dengan menggunakan rumus sebagai berikut:

Normalized $T W I=\frac{\mathrm{a}+((\mathrm{x}-\mathrm{A})(b-a)}{(\mathrm{B}-\mathrm{A})}$

Dimana:

$\mathrm{a}=$ nilai normalisasi terendah, yaitu 0

$\mathrm{b}=$ nilai normalisasi tertinggi, yaitu 1

$\mathrm{x}=$ nilai $\mathrm{TWI}$

$A=$ nilai TWI aktual terendah

$\mathrm{B}=$ nilai TWI aktual tertinggi

Semakin besar nilai TWI maka semakin besar potensi untuk terjadi genangan di suatu daerah (Pourali et.al., 2014). Penentuan daerah rawan banjir genangan juga diasosiasikan dengan keberadaan sungai.

Data pendukung dalam penelitian ini antara lain data kejadian bencana banjir di Kabupaten Kebumen serta data survei lapangan mengenai kondisi fisik wilayah. Data pendukung tersebut digunakan sebagai validasi terhadap hasil pemetaan kerawanan banjir.

\section{Hasil dan Pembahasan}

\subsection{Gambaran Umum Wilayah Kajian}

Kabupaten Kebumen secara morfologi terdiri dataran, perbukitan dan pegunungan (Gambar 1). Morfologi pegunungan merupakan jajaran Pegunungan Serayu Selatan yang berada di bagian utara Kabupaten Kebumen. Pegunungan Serayu Selatan merupakan hulu dari sungai-sungai yang mengalir di Kabupaten Kebumen. Daerah dengan morfologi perbukitan berada di bagian barat yang berupa Perbukitan Karst Gombong Selatan. Sebagian besar daerah Kabupaten Kebumen merupakan dataran. Penggunaan lahan yang dominan pada daerah dataran adalah permukiman dan lahan pertanian.

Kondisi morfologi memberikan dampak dalam bidang kebencanaan khususnya banjir. Banyaknya sungai yang mengalir melewati Kabupaten Kebumen menjadikan daerah ini memiliki potensi bencana banjir. Luasnya morfologi dataran di Kabupaten Kebumen berpotensi menjadi daerah terdampak banjir. 


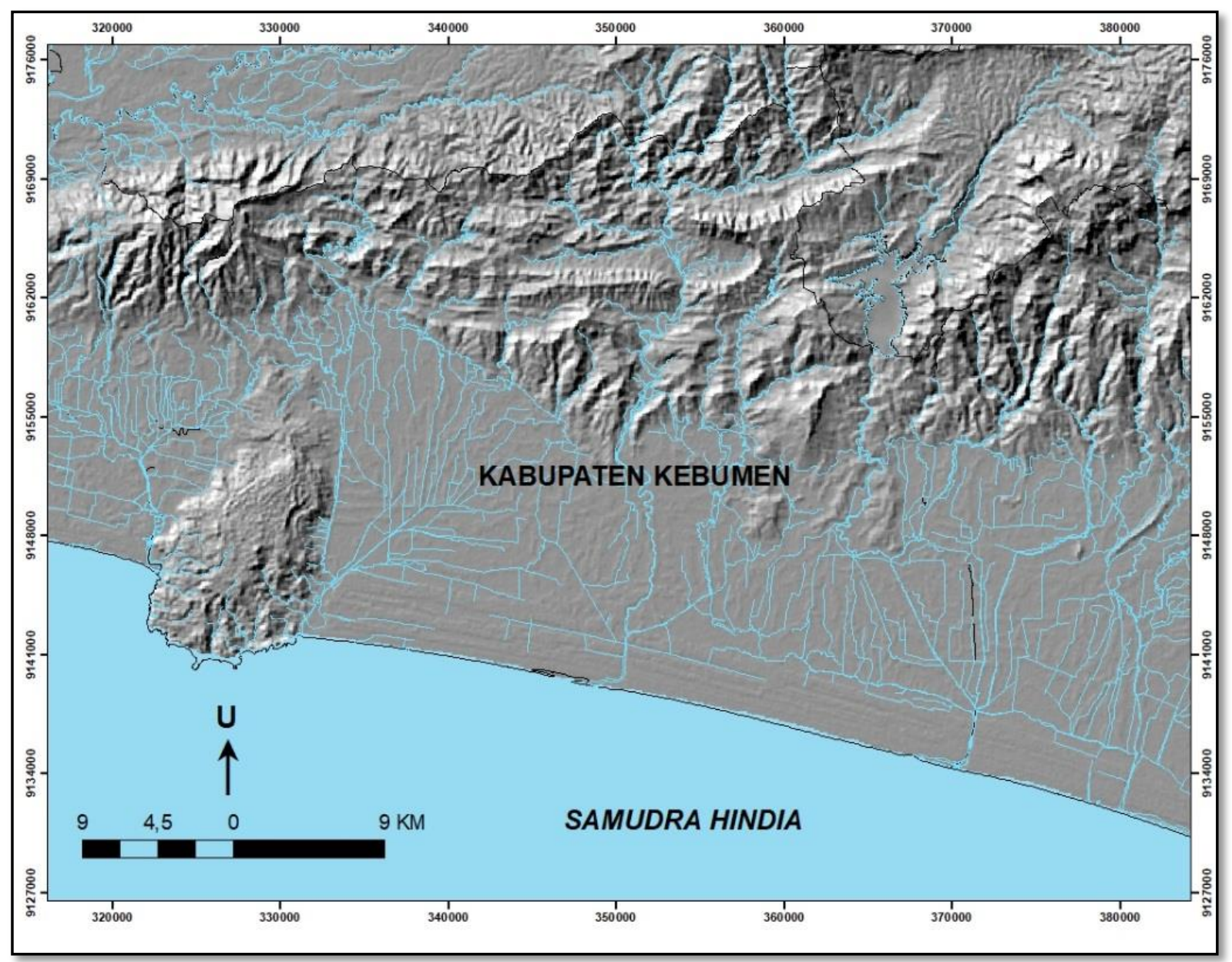

Gambar 1. Kondisi morfologi Kabupaten Kebumen

\subsection{Sebaran Spasial TWI (Topograhic Wetness Index)}

Nilai TWI ditentukan berdasarkan topografi. Perhitungan nilai TWI didasarkan pada nilai elevasi pada data DTM. Nilai TWI maksimum sebesar 12,7044 dan nilai minimum sebesar 2,7604. Normalisasi nilai TWI dilakukan untuk mempermudah analisis. Nilai TWI dinormalisasikan menjadi interval 0-1.

Semakin besar nilai TWI menunjukkan bahwa daerah tersebut merupakan akumulasi air. Berdasarkan hasil normalisasi nilai TWI, nilai TWI yang mendekati 1 berada pada daerah dataran sedangkan nilai TWI mendekati 0 berada pada topografi perbukitan dan pegunungan (Gambar 2).

Nilai TWI yang tinggi berasosiasi dengan dataran dan cekungan. Pada kasus ini besarnya nilai TWI berasosiasi dengan tingginya kerapatan aliran. Daerah dengan nilai TWI yang tinggi berada dekat dengan saluran baik itu sungai ataupun saluran irigasi.

Pada penelitian ini data DEM yang digunakan memiliki resolusi 10 meter. Oleh karena itu level analisis yang dapat dilakukan hanya sampai pada skala menengah. 


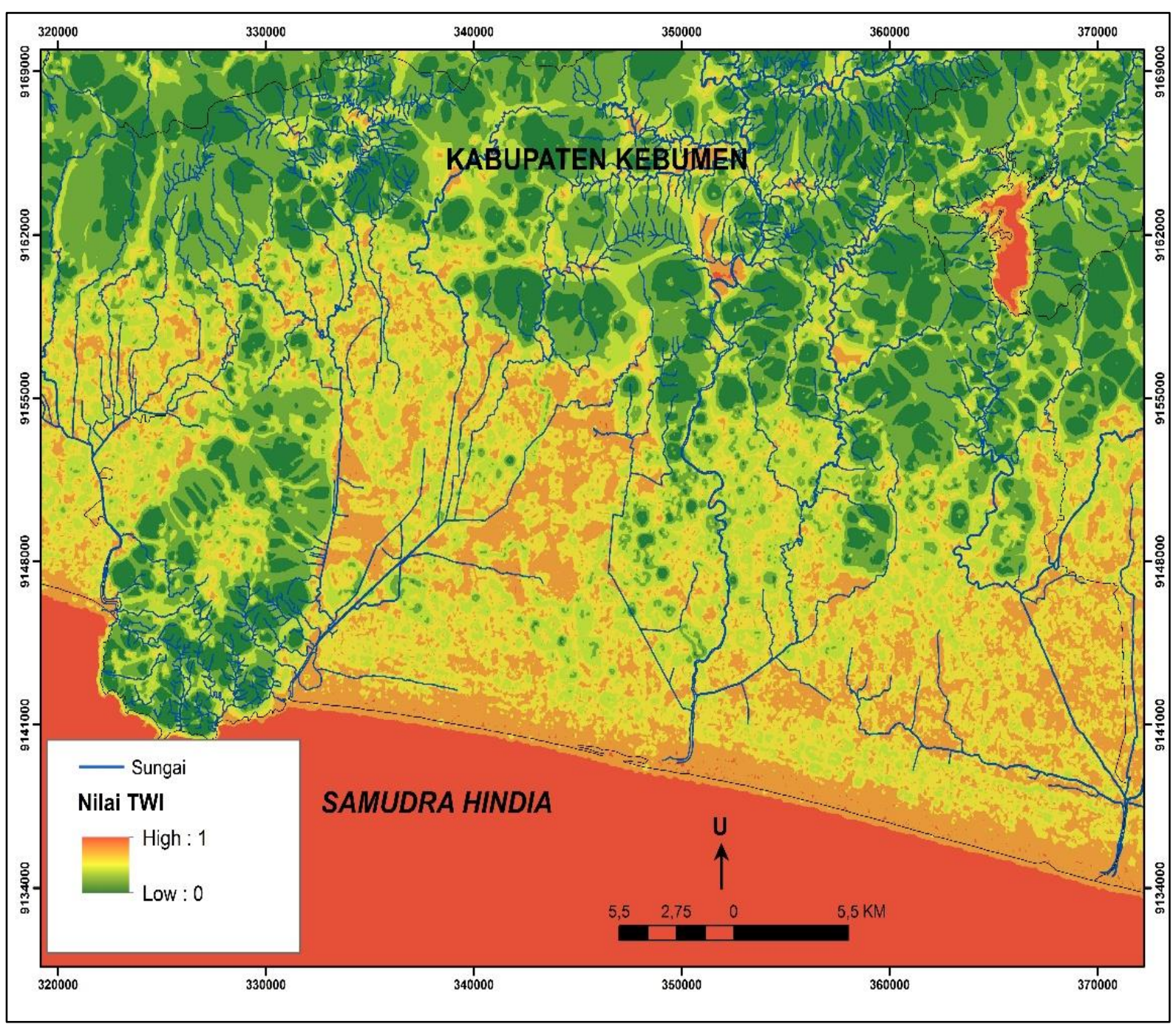

Gambar 2. Sebaran spasial nilai TWI (Topographic Wetness Index)

\subsection{Kerawanan Banjir}

Tingkat kerawanan banjir ditentukan berdasarkan nilai TWI. Berdasarkan nilai TWI, daerah rawan banjir di Kabupaten Kebumen berada di bagian tengah. Daerah tersebut memiliki topografi yang datar dengan kerapatan aliran yang tinggi (Gambar 3).
Pemanfaatan TWI untuk deteksi kerawanan banjir hanya cocok dilakukan untuk banjir genangan. Untuk kasus lain seperti banjir bandang, pemanfaatan TWI kurang efektif. Hal ini dikarenakan banjir bandang memiliki faktor penyebab yang lebih kompleks sehingga membutuhkan parameter yang lebih banyak dalam menentukan kerawanan banjir. 


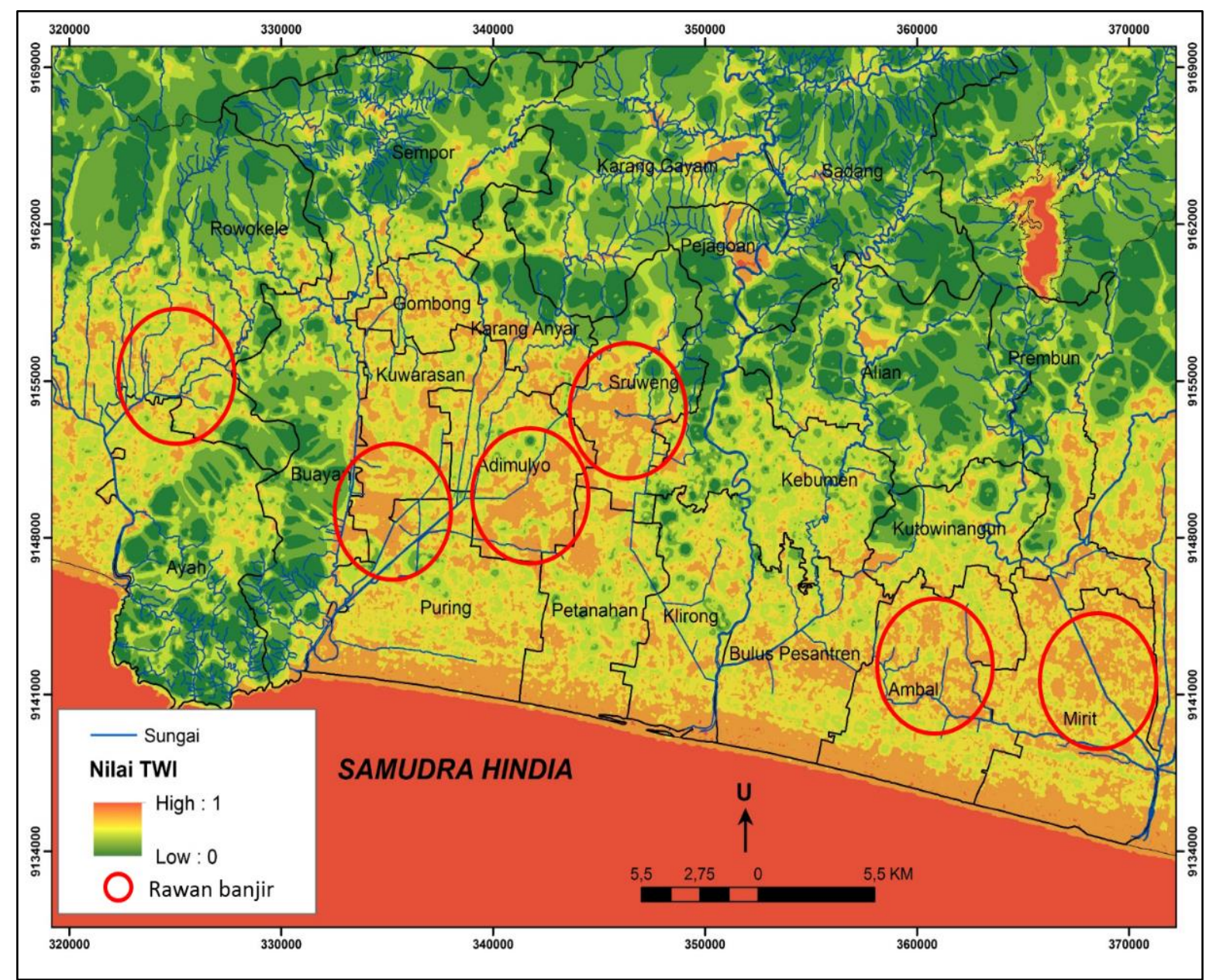

Gambar 3. Sebaran spasial daerah rawan banjir di Kabupaten Kebumen

Bencana banjir di Kabupaten Kebumen merupakan bencana periodik yang selalu terulang pada setiap musim penghujan. Secara garis besar, daerah rawan banjir di Kabupaten Kebumen terbagi menjadi enam area. Enam area tersebut mencakup Kecamatan Adimulyo, Kecamatan Sruweng, Kecamatan Buayan, Kecamatan Mirit, Kecamatan Ambal dan Kecamatan Rowokele. Validasi data hasil deteksi kerawanan banjir dilakukan dengan survei lapangan.
Berdasarkan hasil survei lapangan, enam daerah tersebut memang pada faktanya rawan banjir. Banjir terjadi akibat luapan sungai yang berada di sekitar area tersebut. Kejadian banjir hampir selalu terjadi pada setiap musim penghujan. Bencana banjir mengakibatkan kerugian pada berbagai aspek, antara lain genangan pada permukiman, kegagalan panen dan kerusakan infrastruktur (Gambar 4). 


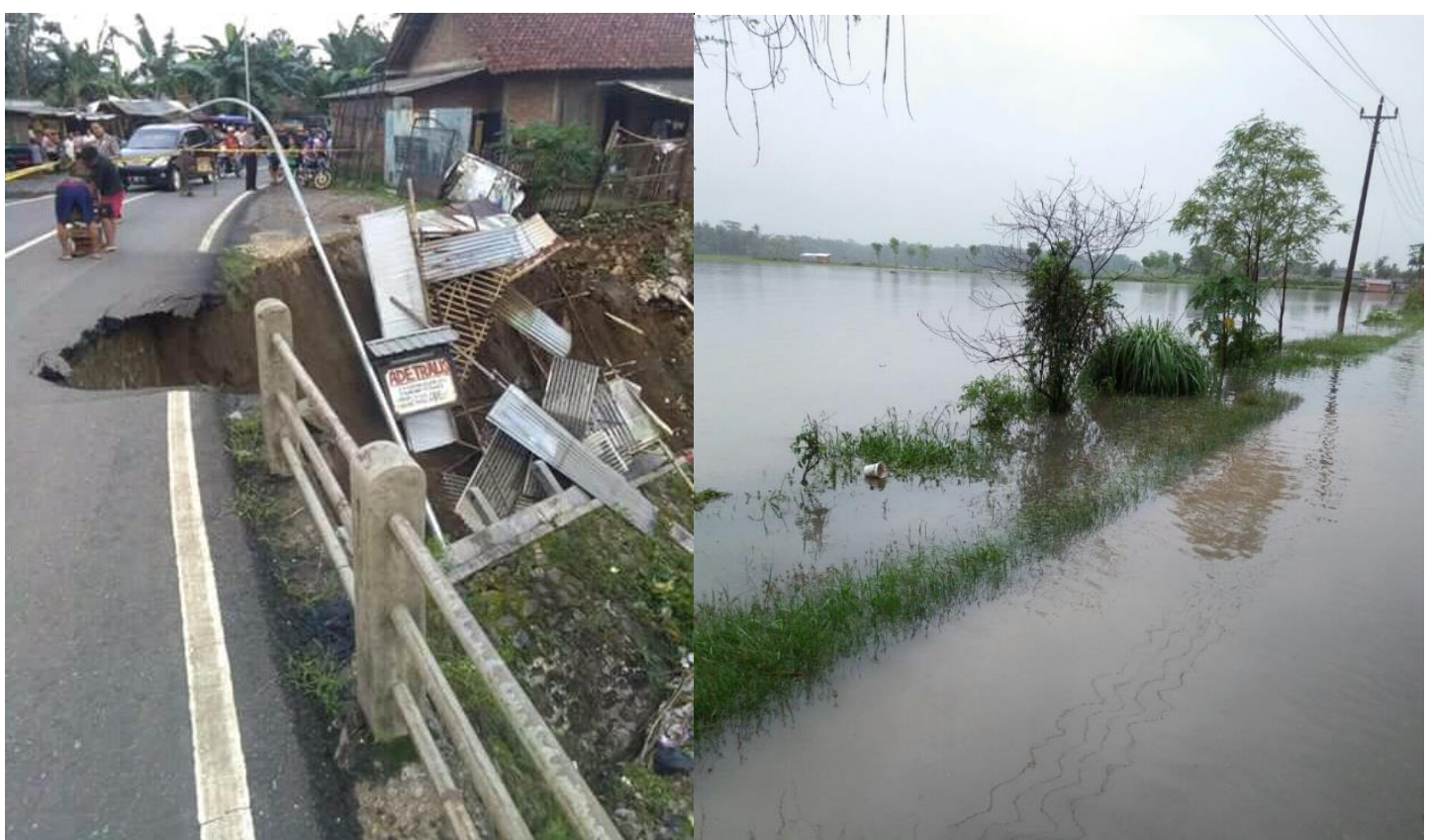

Gambar 4. a) Jembatan Sungai Jatinegara ambrol di Desa Mergosono, Kecamatan Buayan;

b) Lahan pertanian dan jalan tergenang banjir di Kecamatan Adimulyo

(Sumber: Dokumentasi Lapangan, 2017)

Kecamatan Adimulyo merupakan daerah dengan tingkat kerawanan banjir paling tinggi. Setiap musim penghujan daerah ini selalu menjadi langganan banjir. Banjir di Kecamatan Adimulyo mengakibatkan kerugian yang besar terutama pada sektor pertanian. Sebagian besar genangan terjadi di lahan pertanian penduduk (Gambar 5). Genangan tersebut akan berlangsung lama karena topografi Kecamatan Adimulyo yang datar cenderung ke arah cekung.

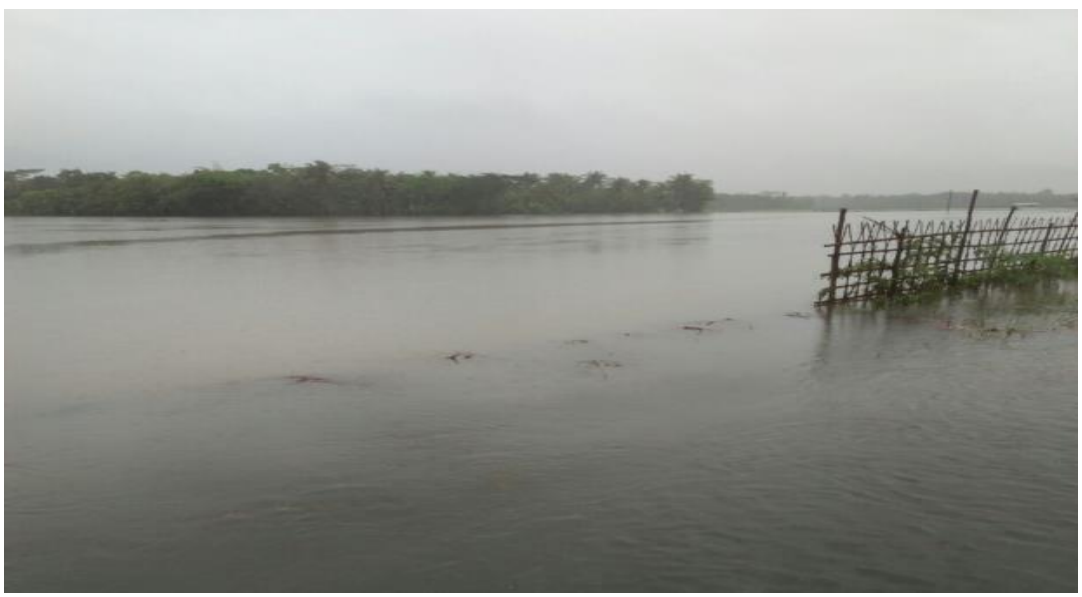

Gambar 5. Banjir menggenangi lahan pertanian di wilayah Kecamatan Adimulyo (Sumber: Dokumentasi Lapangan, 2017) 
Hal lain yang menyebabkan Kecamatan Adimulyo rawan banjir adalah banyaknya sungai yang melewati daerah ini. Total ada 9 sungai besar dan kecil yang melewati daerah ini. Sungai-sungai tersebut antara lain Sungai Kemit, Sungai Karanganyar, Sungai Kejawang, Sungai Abang, Sungai Turus, Sungai Joho, Sungai Kanoman, Sungai Wungu dan Sungai Clebok. Sungai-sungai tersebut bermuara pada Sungai Telomoyo di bagian selatan. Kecamatan Adimulyo menjadi bagian dari DAS Telomoyo yang merupakan salah satu DAS besar di Kabupaten Kebumen. Luas DAS Telomoyo sebesar 51.560,172 $\mathrm{Ha}$ (BPDAS Serayu Opak Progo, 2009).

Pemanfaatan TWI dalam penentuan kerawanan banjir dinilai cukup efektif karena sesuai dengan kondisi yang terjadi di lapangan. Metode ini dapat digunakan untuk melakukan flood rapid assessment . Untuk melakukan pemodelan banjir yang lebih detail diperlukan resolusi data DEM yang lebih detail serta data parameter banjir lain seperti curah hujan dan jenis tanah.

\section{Penutup}

Topographic Wetness Index (TWI) menggambarkan nilai kebasahan lahan yang dihitung berdasarkan kondisi topografi. Perhitungan nilai TWI dilakukan dengan menggunakan data DEM (Digital Elevation Model) dalam bentuk DTM (Digital Terrain Model). Nilai TWI dapat dimanfaatkan untuk menentukan daerah rawan banjir.

Daerah dengan nilai TWI yang tinggi diasumsikan memiliki tingkat kerawanan banjir yang tinggi. Nilai TWI tinggi berasosiasi dengan topografi datar dan kerapatan aliran yang tinggi. Daerah rawan banjir di Kabupaten Kebumen berdasarkan nilai TWI mencakup enam wilayah kecamatan yaitu Kecamatan Adimulyo, Kecamatan Buayan, Kecamatan Ambal, Kecamatan Mirit,
Kecamatan Sruweng dan Kecamatan Rowokele.

Berdasarkan hasil survei lapangan, daerah dengan kerawanan banjir paling tinggi adalah Kecamatan Adimulyo. Hal ini dikarenakan topografi yang datar cenderung ke arah cekung sehingga menjadi daerah akumulasi air. Selain itu daerah tersebut juga dilewati banyak saluran baik itu sungai alami ataupun saluran irigasi.

Pemanfaatan TWI untuk menentukan kerawanan banjir hanya dapat digunakan dalam kasus banjir genangan. Untuk kasus lain seperti banjir bandang, penggunaan TWI tidak efektif karena faktor penyebab banjir bandang lebih kompleks.

Resolusi DEM yang digunakan dalam analisis mempengaruhi kedetilan hasil penelitian. Penelitian ini menggunakan data DEM dengan resolusi 10 meter sehingga analisis yang dilakukan hanya sampai level skala menengah. Untuk pemodelan banjir secara detail diperlukan data DEM dengan resolusi yang lebih tinggi.

\section{Daftar Pustaka}

Aksoy, H., Kirca, VY., Burgan, HI., and Kellecioglu, D. 2016. Hydrological and hydraulic models for determination of flood-prone and flood inundation areas. Proceeding IAHS (373), 137-141.

Aldrian E, Dimitry S, Jacob D, Gates $L$ and Podzun R. 2005. Modelling Indonesian Rainfall with a Coupled Regional Model. Climate Dynamics (25), 1-17.

Beven, KJ and Kirby, MJ. 1979. A physically based, variable contributing area model of basin hydrology. Hydrological Science Bulletin (24), 43-69.

BNPB. 2017. Data dan Informasi Bencana Indonesia. Badan Penanggulangan 
Bencana

Nasional.

http://dibi.bnpb.go.id/data-

bencana/statistik Diakses pada 3 Mei 2017

BPDAS Serayu Opak Progo. 2009. Statistik dan Informasi Balai Pengelolaan DAS Serayu Opak Progo. Yogyakarta: BPDAS Serayu Opak Progo.

Diakakis, Michalis. 2011. A method for lood hazard mappng based on basin morphometry: application in two catchments in Greec. Hydrology and Earth System Scicences, (10), 101 112.

Haas, Jan. 2010. Soil moisture modelling using TWI and satellite imagery in the Stockholm region. MSc Thesis. Stockholm: Royal Institute of Technology (KTH).

Jenson, S., 1991. Applications of hydrologic information automatically extracted from digital elevation models. Hydrological Processes 5:31-44.

Maidment, DR. 1992. Handbook of Hydrology. United States: McGrawHill.

Pourali, SH., Arrowsmith, C., Crisman, N., Matkan, A. and Mitchel, D. 2014. Topography Wetness Index Application in Flood-Risk Based Land Use Planning. Application Spatial Analysis. DOI 10.1007/s12061-014-9130-2.

Price, J., 1990. Using spatial context in satellite data to infer regional scale evapotranspiration. IEEE Transactions on Geoscience and Remote Sensing 28:940-948.

Qin, C. Z., Zhu, A. X., Pei, T., Li, B. L., Scholten, T., Behrens, T., et al. 2011. An approach to computing topographic wetness index based on maximum downslope gradient. Precision Agriculture, 12(1), 32-43.
Quinn, P., Beven, K., Chevallier, P., and Planchon, O. 1991. The prediction of hillslope flow paths for distributed hydrological modelling using digital terrain models. Hydrological Processes, 5(1), 59-79.

Seibert, J., Stendahl, J. and Sørensen, R., 2007. Topographical influences on soil properties in boreal forests. Geoderma 141:139-148.

Sorensen, R., Zinko, U., and Seibert.J. 2006. On the calculation of the topographic wetness index: evaluation of different methods based on field observation. Hydrology and Earth System Scicences, (10), 101-112.

Suarna, I Wayan. 2013. Aplikasi Geografi Dalam Penanganan Kebencanaan Lingkungan di Indonesia. Media Komunikasi Geografi, 14 (1).

Wilson, J. P., and Gallant, J. C. 2000. Digital terrain analysis. Terrain analysis: Principles and applications, 1-27.

Wolock, D. and Price, C., 1994. Effects of digital elevation model map scale and data resolution on a topographybased watershed model. Water Resources Research 30:3041-3052.

WMO. 2009. Integrated Flood Management. Concept Paper. Geneva: World Meteorological Organization.

Wilson, J. P., and Gallant, J. C. 2000. Digital terrain analysis. Terrain analysis: Principles and applications, 1-27.

Wolock, D. and Price, C., 1994. Effects of digital elevation model map scale and data resolution on a topographybased watershed model. Water Resources Research 30:3041-3052.

WMO. 2009. Integrated Flood Management. Concept Paper. Geneva: World Meteorological Organization. 